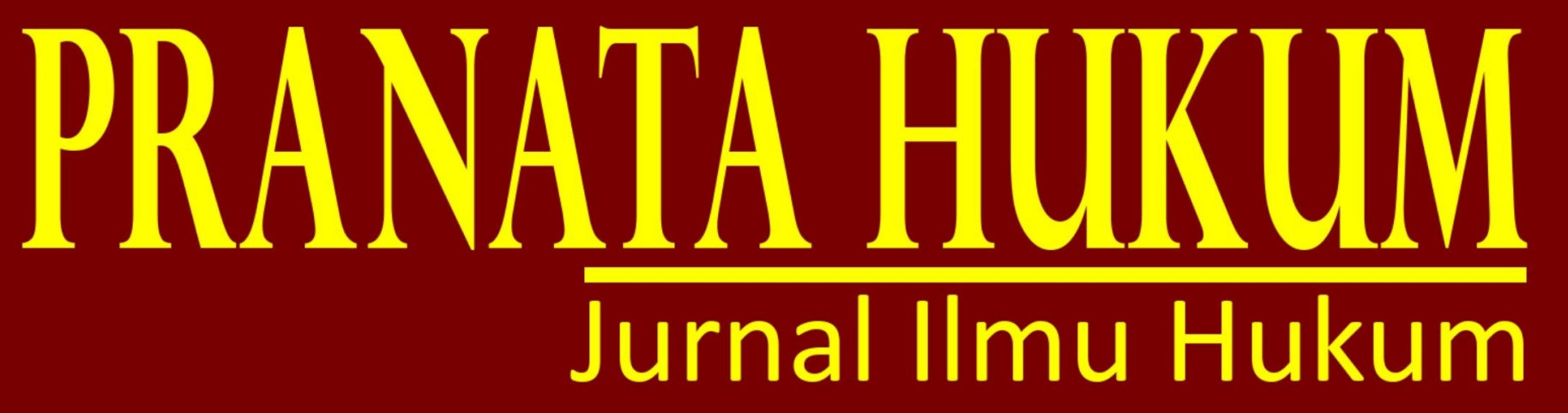

e-ISSN 2685-3213 | p-ISSN 1907-560X

EFEKTIVITAS ASEAN CONVENTION ON COUNTER TERRORISM DI DALAM MEMBERANTAS PEMBAJAKAN DI WILAYAH PERAIRAN ASIA TENGGARA

Rafi Darajati, Muhammad Syafei

PERLINDUNGAN HUKUM PENGGUNA JALAN DARI ANGKUTAN UMUM ONLINE PADA PENGGUNAAN TELEPON SAAT MENGEMUDI KENDARAAN

Rissa Afni Martinouva

ANALISIS PERTANGGUNGJAWABAN PELAKU TINDAK PIDANA MELAKUKAN PENEBANGAN POHON DALAM KAWASAN HUTAN TANPA IJIN YANG BERWENANG

Sukoco SP, Erlina B , Eddy S Wirabhumi

PERLINDUNGAN HUKUM PASIEN PADA BIDAN PRAKTIK MANDIRI DI INDONESIA PASCA DIKELUARKANNYA UNDANG-UNDANG NOMOR 4 TAHUN 2019 TENTANG KEBIDANAN Aditia Arief Firmanto

FUNGSI PENGAWASAN PERADILAN TATA USAHA NEGARA TERHADAP PERBUATAN PEMERINTAH PASCA UNDANG-UNDANG NOMOR 30 TAHUN 2014 TENTANG ADMINISTRASI PEMERINTAHAN Muhammad Rusjana

PELAKSANAAN PENGADAAN BARANG/JASA PEMERINTAH DITINJAU DARI PERPRES NOMOR 16 TAHUN 2018 TENTANG PENGADAAN BARANG/JASA PEMERINTAH DI KANTOR PERTANAHAN KOTA BANDAR LAMPUNG Aryana Wisastra, Baharudin, Indah Satria

KEWAJIBAN TANGGUNG JAWAB SOSIAL PERUSAHAAN (CORPORATE SOCIAL RESPONSIBILITY) DI INDONESIA: ANTARA LEGAL OBLIGATION ATAU MORAL OBLIGATION

Dani Amran Hakim, Dania Hellin Amrina

IMPLEMENTASI PERATURAN MENTERI AGRARIA DAN TATA RUANG/KEPALA BADAN PERTANAHAN NASIONAL NOMOR 13 TAHUN 2017 TENTANG TATA CARA BLOKIR DAN SITA PADA KANTOR PERTANAHAN KOTA BANDAR LAMPUNG

Sholin Erbin M Rajagukguk, Lintje Anna Marpaung, Herlina Ratna Sumbawa Ningrum

PEMBERIAN PATEN OBAT-OBATAN DAN PEMENUHAN HAK ASASI MANUSIA TERHADAP KESEHATAN DI INDONESIA

Chandra Muliawan

\begin{tabular}{c|c|c|c|c|}
\hline $\begin{array}{c}\text { PRANATA } \\
\text { HUKUM }\end{array}$ & $\begin{array}{c}\text { Volume } \\
14\end{array}$ & $\begin{array}{c}\text { Nomor } \\
\mathbf{2}\end{array}$ & $\begin{array}{c}\text { Halaman } \\
96-222\end{array}$ & $\begin{array}{l}\text { Bandar } \\
\text { Lampung } \\
\text { Juli 2019 }\end{array}$ \\
\hline
\end{tabular}




\section{PRANATA HUKUM}

Jurnal Ilmu Hukum

Magister Hukum

Universitas Bandar Lampung

Terbit Pertama Kali, Juli 2006

Terbit Dua Kali Setahun, Setiap Januari dan Juli

PENANGGUNG JAWAB

Rektor Universitas Bandar Lampung

KETUA PENYUNTING

Prof. Dr. Lintje Anna Marpaung, S.H., M.H

\section{WAKIL KETUA PENYUNTING}

Dr. Bambang Hartono, S.H., M.Hum

\section{PENYUNTING PELAKSANA}

Dr. Tami Rusli, S.H., M.Hum

Dr. Erlina B, S.H., M.H

Dr. Zainab Ompu Jainah, S.H., M.H

Indah Satria, S.H., M.H

Yulia Hesti, S.H., MH

\section{PENYUNTING AHLI (MITRA BESTARI)}

Prof. Dr. I Gusti Ayu Ketut Rachmi Handayani, S.H., M.M (Universitas Sebelas Maret) Prof. Dr. I Gede A.B Wiranata, S.H., M.H (Universitas Lampung) Dr. Nurhadiantomo, S.H., M.Hum (Universitas Muhammdiyah Surakarta) Dr. Erina Pane, S.H., M.H (UIN Lampung)

Alamat:

Kampus B Universitas Bandar Lampung

Jl. Z.A Pagar Alam No.89 Labuhan Ratu, Bandar Lampung 35142

Telp: 0721-789825 Fax: 0721-770261

Email: jurnal.mh@ubl.ac.id

\footnotetext{
Jurnal PRANATA HUKUM dimaksudkan sebagai media komunikasi ,edukasi dan informasi ilmiah bidang ilmu hukum. Sajian dan kemasan diupayakan komunikatif melalui bahasa ilmiah.

Redaksi mengundang semua elemen masyarakat ,baik civitas akademika, praktisi, lembaga masyarakat ,maupun perorangan yang berminat terhadap bidang hukum untuk berpartisipasi mengembangkan gagasan, wawasan, dan pengetahuan melalui tulisan untuk dimuat dalam jurnal ini. Melalui PRANATA HUKUM diharapkan terjadi proses pengembangan bidang hukum sebagai bagian penting dari rangkaian panjang proses memajukan masyarakat bangsa
} 


\title{
EFEKTIVITAS ASEAN CONVENTION ON COUNTER TERRORISM DI DALAM MEMBERANTAS PEMBAJAKAN DI WILAYAH PERAIRAN ASIA TENGGARA
}

\author{
Muhammad Rafi Darajati', Muhammad Syafei²
}

\begin{abstract}
Countries in Southeast Asia in the past period are still faced with several acts of piracy and terrorism in the territorial sea. Piracy has a negative effect that is felt by the international community. In this paper, the author aims to focus the discussion on how to implement the ASEAN Convention on Counter Terrorism in overcoming the problem of terrorism in the seas around Southeast Asia. This research is normative juridical conducted by examining library materials or secondary data as basic material to be investigated by conducting a search of the regulations and the literature relating to the problems under study. The results of the study showed that at the convention there was a reference to jointly handling the problem of terrorism in the Southeast Asia region. The implementation of the convention in piracy cases in the waters around Southeast Asia is carried out through the principle of cooperation. However, the implementation of the convention has not been effective because it still faces several obstacles such as the nature of responses to situational terrorism, constraints on state sovereignty and the principle of non-interference among members, differences in sea area awareness.
\end{abstract}

\section{Keywords: Piracy, Terrorism, Southeast Asia}

\section{PENDAHULUAN}

Keamanan laut merupakan isu penting. Hal ini disebabkan laut masih merupakan jalur transportasi utama di dalam pengiriman barang. Negara-negara di Asia Tenggara dalam kurun waktu terakhir masih dihadapkan pada beberapa aksi pembajakan dan terorisme di wilayah perairan. Hal tersebut dikarenakan perairan di Asia Tenggara digolongkan sebagai the most dangerous waters in the world (Mccauley, http://time.com/piracy-southeast-asia-malacca-strait/, akses 29 April 2019). Masalah kerawanan yang dihadapi negara-negara Asia Tengara sampai saat ini adalah masalah keamanan maritim seperti pembajakan, perampokan, penangkapan ikan secara ilegal, pelangaran wilayah, lalu lintas laut yang terkait dengan gerkan separatisme, ancaman terorisme maritim yang semakin canggih dan bentuk pelanggaran lainnya (Ummar, 2001: 15).

\footnotetext{
1 Dosen Fakultas Hukum Universitas Tanjungpura Pontianak, rafidarajati@untan.ac.id

2 Dosen Fakultas Hukum Universitas Tanjungpura Pontianak, msyafei300@gmail.com
} 
Pembajakan memiliki efek negatif yang sangat dirasakan oleh masyarakat internasional secara keseluruhan, karena menghambat terhadap perdagangan, transportasi dan lain sebagainya. Pembajakan merupakan tindak pidana internasional yang berasal dari kebiasaan yang berkembang di dalam hukum internasional dan disebut sebagai tindak pidana transnasional atau lebih dikenal dengan tindak pidana transnasional terorganisasi (Santoso, 2014: 110).

Menurut telusuran data yang penulis lakukan, di tahun 2015 tercatat terdapat 11 perampokan terhadap kapal di wilayah perairan sekitar Association of Southeast Asian Nations (ASEAN) (Espenella, http://thediplomat.com /2016/05/abductions -at-sea-a-3-way-security-challenge-for-indonesia-malaysiaand-the-philippines/, akses 25 April 2019). Pola pembajakan dan terorisme di wilayah perairan ini mulai merubah pola yang tadinya merebut kapal atau barang bawaan, menjadi penculikan yang meminta tebusan di awal tahun 2016. Hal inilah yang terjadi pada kasus perampokan kapal Brahma 12, Anand 12, MV Massive 6, dan TB Henry (Espenella, http://thediplomat.com/2016/05/ abductions-at-sea-a3-way-security-challenge-for-indonesia-malaysia-and-the-philippines/, akses 25 April 2019).

Permasalahan pembajakan dan terorisme ini sudah menjadi hirauan negara-negara di dunia, hal tersebut telah dibuktikan dengan lahirnya United Nations Convention on the Law of the Sea 1982 (Konvensi Hukum Laut 1982) dan Convention for the Suppression of Unlawful Acts of Violence against the Safety of Maritime Navigation 1988 (Konvensi Penekanan terhadap Tindakan Melawan Hukum dalam Keamanan Navigasi Maritim 1988) yang mengatur mengenai tindakan pembajakan di laut. Khusus di wilayah Asia Tenggara, sejak sebelum peristiwa 9/11, negara-negara ASEAN telah mengadopsi Declaration on Transnational Crime pada 1997 dan tahun 1999 menyepakati ASEAN Action Plan to Combat Transnational Crime.Didorong dengan peristiwa penyerangan terhadap Amerika Serikat tahun 2001, semakin mendorong negara-negara ASEAN untuk melakukan deklarasi Joint Action to Counter Terrorism (Pushpanathan, http://asean.org/?static_post=asean-efforts-to-combat-terrorism-byspushpanathan, akses 25 April 2019). Pada tahun 2007, ASEAN juga menghasilkan dokumen yang begitu penting dalam upaya pemberantasan terorisme di kawasan Asia Tenggara, yaitu ASEAN Convention on Counter Terrorism. Bahkan pada perkembangan terbaru pada cetak biru pilar Politik dan Keamanan Masyarakat ASEAN juga dicantumkan di poin B.4.2. mengenai upaya penanggulangan terorisme dan mendorong implementasi Konvensi ASEAN dalam Melawan Terorisme (ASEAN, 2009: 12).

Konvensi-konvensi mengenai terorisme mengedepankan efektifitas penuntutan secara nasional terhadap tindakan terorisme serta bentuk pencegahan. Salah satu kewajiban utama adalah agar negara peserta memberikan bantuan dalam proses persidangan dan pada tahap ekstradisi. Tanpa adanya 
sebuah mahkamah pidana internasional yang khusus untuk mengadili pembajakan di laut, maka sanksi pidana dan perdata diserahkan kepada negara yang menangkap ataupun menahan pelaku, serta tuntutan dilakukan di pengadilan nasionalnya (Cryer, et. al, 2010: 340).

Meskipun demikian, penulis melihat kasus pembajakan di tahun 2016 memperlihatkan bahwa upaya-upaya yang dibangun selama sejak 2001 belum begitu efektif. Dikarenakan pada periode waktu yang berdekatan, yaitu akhir Maret dan awal April 2016, sudah terjadi 3 pembajakan kapal yang dilakukan oleh kelompok yang sama. Kelompok terorisme yang bertanggungjawab atas kasuskasus pembajakan kapal di awal tahun 2016 adalah Abu Sayyaf. Keberadaan kelompok Abu Sayaf, sebagai aktor terorisme yang beraktifitas di perairan utara Pulau Kalimantan, menjadi ancaman tersendiri bagi negara-negara yang berada di sekitarnya.

Berdasarkan pemaparan latar belakang tersebut, penulis ingin memfokuskan pembahasan terkait Bagaimana implementasi ASEAN Convention on Counter Terrorism dalam mengatasi permasalahan terorismedi wilayah perairan sekitar ASEAN.Penelitian ini bersifat yuridis normatif yang dilakukan dengan cara meneliti bahan pustaka atau data sekunder sebagai bahan dasar untuk diteliti dengan cara mengadakan penelusuran terhadap peraturan-peraturan dan literatur-literatur yang berkaitan dengan permasalahan yang diteliti (Soekanto dan Mamuji, 2006: 13).Sifat penulisan yuridis normatif dianggap sesuai untuk mengetahui konteks berlangsungnya ASEAN Convention on Counter Terrorism di tiga negara, yaitu Indonesia, Malaysia, dan Filipina. Penulis memilih tipe deskriptif dalam melakukan penulisan ini. Hal ini didasarkan pada alasan penentuan teori terhadap masalah dan penentuan unit analisis terlebih dahulu yang dilakukan sehingga rumusan masalah menyesuaikan penentuan kedua hal tersebut. Diharapkan penulis dapat mengungkapkan konteks berlangsungnya ASEAN Convention on Counter Terrorism dalam penanggulanan masalah terorisme di wilayah perairan sekitar ASEAN.

\section{PEMBAHASAN}

a. Pengaturan Mengenai Pembajakan Laut Menurut Konvensi Hukum Laut 1982

Kejahatan pembajakan laut telah muncul sejak lama. Hal tersebut dapat dibuktikan dengan telah ada salah satu hukum tertulis yang diberlakukan untuk mengatasi masalah pembajakan laut, yakni adalah the Piracy Act 1698 yang disahkan oleh parlemen Inggris, bahwa bagi yang melakukan pembajakan laut atau perampokan akan dianggap sebagai penjahat dan mereka akan dihukum atas perbuatan pembajakan tersebut. Hukumannya pun sampai dengan hukuman mati dan penyitaan atas kepemilikan tanah atau properti. the Piracy Act 1698 segara diikuti oleh beberapa negara Eropa lainnya seperti Perancis. Di masa lalu ataupun 
masa sekarang bagi negara yang memanfaatkan laut sebagai jalur perdagangannya, setiap tindakan pembajakan laut dapat mengancam kegiatan mereka dan karenanya melanggar kepentingan semua negara yang terlibat dalam perdagangan tersebut. Hal tersebut yang menjadi alasan mengapa kejahatan pembajakan laut di dunia internasional dianggap sebagai musuh seluruh umat manusia (hostis humani generis) (Mulyono, Indonesian Journal of International Law, no. 1, Oktober 2014: 60-83).

Selain itu dikatakan pembajakan laut juga apabila dilakukan oleh kapal perang atau kapal pemerintah lainnya jika awak kapalnya telah melakukan pemberontakan dan menguasai kapal untuk melakukan tindakan pembajakan. Hal tersebut telah diatur di dalam pasal 102 Konvensi Hukum Laut 1982 yaitu:

The acts of piracy, as defined in article 101, committed by a warship,government ship or government aircraft whose crew has mutinied and taken control of the ship or aircraft are assimilated to acts committed by a private ship or aircraft.

Namun, kejadian di kawasan Selat Malaka merupakan salah satu contoh dimana selat tersebut benar-benar masuk ke dalam wilayah berbagai negara pantai, padahal sudah menjadi kawasan yang paling rawan terhadap tindakan pembajakan laut dikarenakan kedalaman yang tidak teratur sehingga mendorong berbagai kapal untuk melakukan pelayaran dengan kecepatan yang minimum sehingga menjadi sasaran bagi para pembajak. (Mccauley, http://time.com/piracysoutheast-asia-malacca-strait/, akses 13 April 2019). Jika pembajakan terjadi di kawasan tersebut maka pembajakan tersebut tidak termasuk ke dalam pengaturan hukum internasional, dengan demikian masyarakat internasional tidak dapat menerapkan yurisdiksi universal. Masalah ini yang terjadi di Perairan Utara Pulau Kalimantan. Di mana pada beberapa kasus pembajakan yang dilakukan oleh Abu Sayyaf terjadi di wilayah teritorial masing-masing negara.

Syarat lain suatu tindakan termasuk dalam pembajakan laut adalah harus dilakukan oleh awak dari kapal pribadi lainnya maka apabila ada suatu kapal yang terjadi pengambilalihan oleh awak atau penumpangnya sendiri maka bukan dikatakan sebagai tindakan pembajakan laut atau apabila terjadi suatu tindak pidana murni dan sederhana yang terjadi di kapal tersebut maka bukan termasuk kategori pembajakan laut.

Mengenai tindakan pembajakan yang dilakukan oleh kelompok Abu Sayyaf, maka termasuk kedalam kategori pembajakan laut dikarenakan mereka menggunakan speed boat untuk datang ke kapal korban. Hal tersebut dijelaskan oleh Chief Officer Kapal Brahma 12, Julian Phillip, yang kapalnya dibajak pada 25 Maret 2016 (Tashandra, http://nasional.kompas.com/read/2016/05/02 /16455111/Ini.Kronologi.Penyanderaan.10.ABK.oleh.Kelompok.Abu.Sayyaf, akses 18 April 2019). 
Maka dapat disimpulkan bahwa harus ada tujuan pengambilalihan atau penguasaan kapal dan/atau barang-barang di atasnya yang digunakan untuk kepentingan pribadi agar dapat dikatakan sebuah tindakan pembajakan laut (Oppenheim, International Law A Treatise,no. 1, 1955: 614).

Syarat selanjutnya adalah agar dapat dikatakan sebagai tindakan pembajakan laut yakni tindakan tersebut merupakan tujuan pribadi. Apabila dikaitkan dengan tindakan pembajakan yang dilakukan oleh kelompok Abu Sayyaf maka kembali masuk ke dalam kategori ini. Dimana dikatakan oleh Panglima TNI pada saat itu Jenderal Gatot Nurmantyo, pembajakan kapal Anand 12 yang dilakukan oleh Abu Sayyaf memiliki motif ekonomi, yakni ketika telah mensandera penumpang kapal meminta uang tebusan (Tempo.co, https:// m.tempo.co/read/news/2016/03/30/078758151/panglima-tni-ungkap-motifpembajakan-kapal-oleh-abu-sayyaf, akses 18 April 2019).

Berdasarkan penjelasan pasal-pasal di atas, terdapat 6 (enam) hal penting yang berkaitan dengan definisi dari pembajakan laut ini, yakni (Kraska, 2011: 127):

1. Penentuan pembajakan laut memerlukan lingkup geografis yang dalam hal ini harus berada di laut lepas dan perairan di luar laut teritorial

2. Pembajakan laut membutuhkan unsur kepentingan pribadi, dimana pembajakan yang dilakukan tersebut murni memiliki motif pribadi

3. Harus terdapat dua kapal yang terlibat di dalam kegiatan pembajakan laut tersebut, dua kapal ini adalah satu kapal yang dibajak dan yang lainnya adalah kapal yang digunakan untuk membajak

4. Terdapat pengertian yang jelas mengenai kapal pembajak

5. Pembajakan laut juga meliputi tindak pidana yang belum selesai, seperti percobaan pembajakan

6. Terdapat perbedaan yang jelas terhadap kapal publik dan kapal privat. Hanyan kapal publik yang dapat menindak pembajakan laut.

Adapun suatu kapal dianggap kapal pembajak apabila ia dimaksudkan oleh orang yang mengendalikannya digunakan untuk tujuan melakukan salah satu tindakan yang dimaksud dalam pasal 101 Konvensi Hukum Laut 1982. Hal yang sama berlaku apabila kapal itu telah digunakan untuk melakukan setiap tindakan tersebut selama kapal itu berada di bawah pengendalian orang-orang yang bersalah melakukan tindakan itu (Pasal 103 Konvensi Hukum Laut 1982). Meskipun begitu, suatu kapal tetap dapat memiliki kebangsaannya walaupun telah menjadi suatu kapal pembajak. Tetap dimilikinya atau kehilangan kebangsaan ditentukan oleh undang-undang negara yang telah memberikan kebangsaan itu (Pasal 104 Konvensi Hukum Laut 1982). Pasal 101 Konvensi Hukum Laut 1982 ini memiliki makna bahwa ketika kapal telah dibajak maka yurisdiksnya tidak hanya menjadi yurisdiksi negara bendera kapal tersebut karena telah menjadi yurisdiksi 
universal, namun kapal tersebut tetap mempunyai kebangsaaan dari negara pendaftar kapal (Kraska, 2011: 132).

Implikasi dari yurisdiksi universal ini adalah maka setiap negara dapat menyita suatu kapal pembajak atau suatu kapal yang telah diambil oleh pembajak dan berada di bawah pengendalian pembajak dan menangkap orang-orang yang membajak barang yang ada di kapal. Pengadilan nasioal dari negara yang telah melakukan tindakan penyitaan itu dapat menetapkan hukuman yang akan dikenakan, dan juga dapat menetapkan tindakan yang akan diambil berkenaan dengan kapal-kapal tersebut (Pasal 105 Konvensi Hukum Laut 1982). Pasal ini mengamantkan suatu keleluasaan bagi negara peserta konvensi untuk memberantas dan menekan tindakan pembajakan laut ini.

Konvensi Hukum Laut 1982 juga mewajibkan bagi negara peserta konvensi dalam rangka untuk memberantas kegiatan pembajakan laut untuk saling bekerja sama, kewajiban tersebut terlihat di dalam pasal 100 yang berbunyi:All States shall cooperate to the fullest possible extent in the repression of piracy on the high seas or in any other place outside the jurisdiction of any State.

Apabila negara peserta kovensi tidak melakukan kewajiban tersebut maka negara tersebut dianggap telah lalai di dalam mengimplementasikan Konvensi Hukum Laut 1982. Salah satu bentuk upaya bagi negara peserta yang bisa dilakukan untuk melaksanakan kewajiban pasal 100 tersebut adalah lewat perundang-undangan nasional yang mengatur kriminalisasi pembajakan laut dan memanfaatkan hukum nasionalnya tersebut untuk melakukan penuntutan terhadap para perompak (Shaw, 2003: 593).

Terkait dengan tindakan pembajakan laut yang dilakukan oleh kelompok Abu Sayyaf maka Indonesia, Malaysia, dan Filipina yang telah meratifikasi Konvensi Hukum Laut 1982 berturut-turut pada 3 Februari 1986, 14 Oktober 1996, dan 8 Mei 1984 (Anonim, http://www.un.org/depts/los/reference _files/chronological_lists_of_ratifications.htm, akses 15 April 2019) harus melaksanakan kewajibannya yang salah satunya adalah berkerjasama di dalam memberantas kegiatan pembajakan laut yang pada akhir-akhir ini marak dilakukan oleh kelompok Abu Sayyaf.

Salah satu yang menjadi alasan adalah kasus pembajakan, seperti yang telah dijelaskan sebelumnya, merupakan suatu kejahatan yang melintasi batas negara serta berhubungan dengan kepentingan dua negara atau lebih. Khusus pada kasus pembajakan laut yang terjadi di perbatasan Indonesia, Malaysia, dan Filipina terlihat bahwa aksi pembajakan dilakukan oleh kelompok teroris Abu Sayyaf. Kemudian aksi pembajakan menarget kapal-kapal berkebangsaan Indonesia atau Malaysia yang juga mempekerjakan beberapa warga negara Asia Tenggara lainnya.

\section{b. Ancaman Terorisme di Asia Tenggara}

Terorisme sebagai sebuah kejahatan memiliki ciri khas. Pertama adalah depersonalisasi korban, yakni dalam tindak pidana terorisme siapa korbannya 
tidak menjadi persoalan yang begitu penting. Terorisme dalam menyerang atau memilih korban dilakukan secara acak. Kedua, terorisme sebagai sebuah kejahatan internasional harus terkait dengan konflik bersenjata internasional atau wilayah yang dijadikan aksi mereka tidak terbatas hanya kepada salah satu wilayah tertentu (Thontowi, 2016: 258)

Adapun The Arab Convention For The Suppression of Terrorism 1998 memberikan pengertian mengenai terorisme, bahwa terorisme adalah (Pasal 1 ayat (3) The Arab Convention For The Suppression Of Terrorism):

any act or threat of violence, whatever its motives or purposes, that occurs in the advancement of an individual or collective criminal agenda and seeking to sow panic among people, causing fear by harming them, or placing their lives, liberty and security in danger, or seeking to cause damage to the environment or to public or private installations or property or occupying or seizing them, or seeking to jeopardize a national resource

Pengertian yang dikutip di atas telah menjadi pedomanbagi penentuan apa yang dimaksud dengan terorisme merupakan sebuah kejahatan internasional yang diakui oleh hukum kebiasaan internasional sehingga tidak semata kewajiban yang hadir dari hukum tapii juga kewajiban yang diakibatkan oleh kebiasaan karena saat ini terbukti terorisme merupakan hostis humanis generis. Kejahatan terorisme internasional memiliki tiga karakter, yaitu pertama, tindakan tersebut haruslah merupakan kejahatan yang dikenal dihampir semua negara di dunia. Kedua, perbuatan ditujukan untuk menghasilkan atau menyebarkan teror. Terakhir perbuatan tersebut haruslah bermotif politik, keagamaan, ideologi, atau tidak bertujuan demi keuntungan pribadi (Thontowi, 2016: 260).

Pada prinsipnya negara-negara di ASEAN sepakat menempatkan aksi terorisme sebagai ancaman terhadap perdamaian dan keamanan internasional. Ancaman itu juga merupakan tantangan bagi upaya merealisasikan Visi ASEAN 2020. Komitmen negara-negara ASEAN sangatlah terlihat dari beberapa pertemuan dan kesepakatan yang telah mereka hasilkan selama ini. Negara-negara ASEAN mengedepankan upaya kerjasama dalam mengatasi masalah terorisme di kawasan (Pushpanathan, http://asean.org/ ?static_post=asean-efforts-to-combatterrorism-by-spushpanathan, akses 25 Arpil 2019).

Kemudian jika kita membahas spesifik mengenai terorisme di wilayah laut, maka kawasan Asia Tenggara menjadi salah satu objek yang menarik. Menurut Kuhnert, letak geografis Asia Tenggara sangat rentan terhadap serangan terorisme di laut karena lautan mendominasi $80 \%$ wilayah Asia Tenggara dan merupakan pusat komunikasi dan perdagangan akibat terletak di antara Samudera Hindia dan Pasifik (Kuhnert, 2006: 8). Alasan lain adalah potensi maritim kawasan Asia Tenggara yang begitu baik ditambah dengan volume perdagangan dilakukan melalui laut. Pada tahun 2012, perdagangan laut mencapai angka 5.9 miliar ton. Bahkan di tahun 2016, hampir separuh dari perdagangan dunia melalui perairan 
Asia Tenggara. Kehidupan masyarakat Asia Tenggara juga bergantung dari perekonomian di laut (Kuhnert, 2006: 8).Melihat dari data-data di atas wajar kemudian jika aksi terorisme laut juga sangat memiliki kesempatan yang banyak.

\section{c. Pembajakan Laut di Wilayah Perairan Sekitar ASEAN: Indonesia, Malaysia, dan Filipina}

Penulis menemukan bahwa terjadi perubahan pola pembajakan yang dilakukan di wilayah perairan sekitar ASEAN, khususnya di laut perbatasan Indonesia, Malaysia, dan Filipina. Secara statistik jumlah pembajakan di tahun 2015 memang cukup banyak sejumlah 11 aksi. Namun, sampai dengan tahun 2015 upaya pembajakan yang dilakukan oleh kelompok teroris murni hanya merampok kapal. Contohnya insiden pembajakan kapal tangker yang bersandar di sekitar Pulau Lembeh, Sulawesi Utara, Indonesia. Pada insiden tersebut, awak kapal dibiarkan bebas dengan menggunakan perahu penyelamat (Espenilla, http://thediplomat.com/2016/05/abductions-at-sea-a-3-way-security-challengefor-indonesia-malaysia-and-the-philippines/, akses 25 April 2019).

Sementara di tahun 2016, perubahan pola pembajakan terjadi dengan mulai meminta uang tebusan bagi para awak kapal. Tiga kasus pembajakan tersebut antara lain terhadap Kapal Brahma 12 dan Anand 12 (Indonesia) pada 26 Maret 2016, MV Massive 6 (Malaysia) pada 1 April 2016, dan TB Henry (Indonesia) pada 15 April 2016. Ketiga kapal ini dibajak bersamaan dengan penawanan awak kapal serta adanya upaya pemintaan tebusan kepada pemilik kapal maupun negara pemilik kapal(Espenilla, http://thediplomat.com/2016/05/abductions-at-sea-a-3way-security-challenge-for-indonesia-malaysia-and-the-philippines/,ak-ses 25 April 2019).

Ketiga kasus di tahun 2016 ini merupakan suatu masalah yang menjadi perhatian ketiga negara. Selain hal ini merupakan suatu masalah keamanan yang penting, juga dikarenakan dalam kurun waktu satu bulan terjadi tiga pembajakan kapal di wilayah laut perbatasan mereka. Tentunya hal ini menjadi suatu permasalahan yang unik. Seolah menunjukkan bahwa terdapat ketidakamanan di laut perbatasan ketiga negara. Ditambah lagi negara-negara di Asia Tenggara sudah menyepakati ASEAN Convention on Counter Terrorism.

\section{d. ASEAN Convention on Counter Terrorism}

Negara-negara di Asia Tenggara yang tergabung dalam keanggotaan ASEAN menyepakati ASEAN Convention on Counter Terrorism di tahun 2007 dan diratifikasi oleh kesepuluh negara ASEAN pada tahun 2013. Jika kita membaca isi konvensi tersebut dapat kita lihat beberapa alasan yang melatarbelakangi disepakatinya konvensi tersebut. Peristiwa terorisme yang terjadi di kawasan Asia Tenggara selama periode 2000-2007, prinsip-prinsip hukum internasional dan resolusi PBB mengenai upaya melawan terorisme, prinsip dalam Treaty of Amity 
and Cooperation in Southeast Asia 1976, diadopsinya ASEAN Declaration on Joint Action to Counter Terrorism dan Declaration on Terrorism pada ASEAN Summits 2001 dan 2002.

Disepakatinya konvensi ini menurut penulis menunjukkan komitmen yang baik di antara negara-negara ASEAN terhadap penanggulangan masalah terorisme. Komitmen negara-negara anggota ASEAN menghadapi masalah terorisme dapat kita telusuri dari beberapa peristiwa bersejarah perkembangan ASEAN. Pertama, ASEAN mengadopsi Declaration on Transnational Crime pada tahun 1997. Kedua, ASEAN mengadopsi ASEAN Action Plan to Combat Transnational Crime pada tahun 1999 untuk mengimplementasi deklarasi sebelumnya (Pushpanathan, http://asean. org/?static post=asean-efforts-to-combat-terrorism-by-spush panathan, akses 25 April 2019). Ketiga, diadopsinya ASEAN Declaration on Joint Action to Counter Terrorism pada pertemuan ASEAN Summit 5 Nopember 2011 yang dihadiri sepuluh kepala negara anggota. Ketiganya menandai pentingnya hirauan terorisme dalam perkembangan ASEAN.

Negara-negara di ASEAN juga menyepakati prinsip dasar dalam melawan terorisme yang dijelaskan oleh Pushpanathan berdasarkan isi dari Declaration on Joint Action to Counter Terrorism, yaitu(Pushpanathan, http://asean.org/?static_post=asean-efforts-to-combat-terrorism-byspushpanathan, akses 25 April 2019):

1. Mengkaji ulang dan menguatkan mekanisme nasional dalam menghadapi terorisme;

2. Mengajukan penyegeraan penandatanganan/ratifikasi sebagian atau seluruh konvensi yang berkaitan dengan anti-terorisme;

3. Kerjasama mendalam antar badan penegak hukum di negara-negara ASEAN dalam menghadapi terorisme dan berbagi pengalaman praktek terbaik;

4. Mempelajari konvensi internasional tentang terorisme untuk menyesuaikan konvensi-konvensi tersebut dengan mekanisme ASEAN dalam menghadapi terorisme internasional.

5. Menambah pertukaran informasi/intelejen untuk mengakomidasi arus informasi mengenai teroris maupun organisasinya, pergerakan dan pendanaan, dan informasi lain yang diperlukan untuk melindungi kehidupan, barang, dan keselamatan perjalanan;

6. Memperkuat kerjasama dan kordinasi antara ASEAN Ministerial Meeting on Transnational Crime (AMMTC) dan badan ASEAN lain yang relevan dengan permasalahan teroris.

7. Mengembangkan program pembangunan kapasitas kawasan untuk meningkatkan kapabilitas anggota ASEAN melakukan investigasti, deteksi, pengawasan, dan pelaporan aksi terorisme.

8. Mendiskusikan dan mengembangkan ide dan inisiatif praktis untuk meningkatkan peran serta keterlibatan ASEAN dalam komunitas 
internasional termasuk kerjasama luar kawasan seperti ASEAN+3, ASEAN Dialogue Partners dan ASEAN Regional Forum, membuat perjuangan melawan terorisme menjadi masalah regional dan global.

9. Meningkatkan kerjasama bilateral, regional, dan internasional dalam mengatasi masalah terorisme.

Beberapa prinsip yang disepakati dalam deklarasi tersebut juga tidak jauh berbeda dengan poin-poin yang disepakati di dalam konvensi. Terlihat bahwa poin kerjasama dan kordinasi menjadi hal yang sangat penting bagi negara-negara ASEAN. Poin-poin penjabaran kerjasama dan kordinasi terlihat dari adanya poin pertukaran informasi/intelejen, pengembangan program kawasan bersama, diskusi, kerjasama antar badan penegak hukum, serta peningkatan kerjasama antar negara. Berikut ini penulis paparkan bagian-bagian dari konvensi tersebut:

1. Ruang lingkup kerjasama yang disetujui dalam ASEAN Convention on Counter Terrorism ini terfokus pada peningkatan kerjasama preventif seperti pertukaran informasi, peningkatan pengawasan perbatasan, pembekuan aset tersangka teroris, perjanjian ekstradisi dan program rehabilitasi serta diutamakan di dalam wilayah yuridiksinya masingmasing. Artinya dalam merumuskan ASEAN Convention on Counter Terrorism, ASEAN berupaya agar segala kebijakan yang berlaku di wilayah Asia Tenggara mengenai kontra terorisme adalah bebas dari kepentingankepentingan di luar kawasan serta konsisten dengan prinsip-prinsip dasar (Yani, Jurnal UNPAD, No. 2, Agustus 2012:72-84)

2. Tujuan dari konvensi ini adalah untuk memberikan suatu kerangka kerja bagi negara anggota ASEAN dalam memberantas segala bentuk terorisme. Hal tersebut tercermin di dalam pasal 1 yakni:

This Convention Shall provide for the framework for regional cooperation to counter, prevent and suppress terrorism in all its forms and manifestations and to deepen cooperation among law enforcement agencies and relevant authorities of the Parties in countering terrorism.

Disepakati tindak pidana terorisme merujuk pada 14 (empat belas) instrumen internasional berhubungan dengan pencegahan dan pemberantasan terorisme. Diantara keempat belas instrumen internasional tersebut, terdapat tiga instrumen internasional yang langsung berkaitan dengan terorisme, yaitu International Convention for the Suppression of Terrorist Bombing, International Convention for the Suppression of the Financing Terrorism, International Convention for the Suppression of Acts of Nuclear Terrorism. Selebihnya dari rujukan tersebut berkaitan dengan konvensi dan protokol berkaitan dengan keselamatan penerbangan dan pelayaran di laut serta keamanan di laut (Pasal 2 ayat (1) ASEAN Convention on Counter Terrorism). 
3. Untuk negara-negara yang tidak bukan negara pihak dari konvensi yang terdapat dalam Pasal 2 ayat (1) tersebut, maka negara tersebut dapat menyatakan bahwa konvensi atau perjanjian tersebut tidak dimasukkan ke dalam Pasal 2 ayat (1) konvensi ini. Tapi pernyataan tersebut tidak akan berlaku ketika negara pihak yang membuat pernyataan tersebut telah menjadi anggota dari perjanjian atau konvensi yang tidak diratifikasi sebelumnya. Ketentuan tersebut diatur di dalam pasal 2 ayat (2).

4. ASEAN Convention on Counter Terrorism merupakan kerangka kerja sama dalam memberantas terorisme berisikan hal-hal yang disetujui oleh negaranegara anggota ASEAN. Adapun kerja sama yang dimuat dalam konvensi ini diharapkan selaras dengan hukum nasional masing-masing negara.

5. Bidang kerjasama yang dimaksud termuat dalam ASEAN Convention on Counter Terrorismterdapat di dalam pasal 6 ayat (1), adapun beberapa kerangka kerja sama tersebut adalah sebagai berikut:

a) Mengambil langkah-langkah yang diperlukan untuk mencegah terjadinya tindakan teroris, termasuk pemberian peringatan dini kepada pihak-pihak lain melalui pertukaran informasi

b) Mencegah siapaun yang mendanai, merencanakan, memfasilitasi, atau melakukan tindakan teroris dari penggunaan wilayah masing-masing untuk tujuan-tujuan melawan pihak-pihak lain

c) Mencegah dan menindak pendanaan tindakan teroris

d) Mencegah pergerakan para teroris atau kelompok-kelompok terorisdengan pengawasan perbatasan yang efektif dan pengawasan penerbitan surat-surat identitas dan dokumen-dokumen perjalanandan melalui langkah-langkah untuk mencegah pemalsuan,penjiplakan, atau penyalahgunaan surat-surat identitas dan dokumen-dokumen perjalanan

e) Memajukan pengembangan kapasitas termasuk pelatihan dan kerjasama teknis dan penyelenggaraan pertemuan-pertemuan regional

f) Meningkatkan kesadaran dan partisipasi masyarakat dalam upaya untuk memberantas terorisme, serta mengembangkan dialog antar kepercayaan dan dalam satu kepercayaan serta dialog antar peradaban

g) Meningkatkan kerja sama lintas batas

h) Meningkatkan pertukaran data intelijen dan tukar menukar informasi

i) Meningkatkan kerja sama yang telah ada untuk pengembangan bank datakawasan di bawah lingkup badan-badan ASEAN yang relevan

j) Memperkuat kapabilitas dan kesiapsiagaan untuk menangani terorisme dengan bahan kimia, biologi, radiologi, nuklir, terorisme dunia maya dan setiap bentuk terorisme baru

k) Melakukan penulisan dan pengembangan langkah-langkah untuk memberantas terorisme 
l) Mendorong penggunaan fasilitas videon-konferensi atau telekonferensi untuk proses peradilan, apabila dimungkinkan

m) Memastikan bahwa siapapun yang terlibat dalam pendanaan, perencanaan, persiapan atau yang melakukan tindakan teroris atau membantu tindakan teroris akan diajukan ke persidangan.

7. Dalam hal pemberian sanksi dan tindakan-tindakan yang diperlukan terhadap tindakan terorisme, setiap negara pihak dapat menetapkan yurisdiksinya sesuai dengan ketentuan konvensi ini. Ketentuan tersebut terdapat di dalam pasal 7 mengenai yurisdiksi negara bahwa suatu negara pihak wajib untuk mengambil langkah-langkah yang diperlukan untuk menetapkan yurisdiksinya terhadap kejahatan-kejahatan yang tercakupi dalam pasal 2 konvensi apabila:

a. Kejahatan dilakukan di wilayah negara pihak yang dimaksud, atau

b. Kejahatan dilakukan di atas kapal berbendera negara pihak yang dimaksud atau di pesawat yang terdaftar menurut peraturan perundang-undangan nasional negara pihak yang dimaksud pada saat kejahatan dilakukan, atau

c. Kejahatan dilakukan oleh warga negara pihak yang dimaksud.

8. Suatu pihak dapat juga menetapkan yurisdiksinya atas setiap kejahatan apabila kejahatan dilakukan terhadap warga negara pihak yang dimaksud atau; kejahatan tersebut dilakukan terhadap fasilitas negara atau pemerintah dari pihak dimaksud di luar negeri, termasuk kedutaan besar atau wilayah diplomatik dan konsuler lainnyaatau; kejahatan itu dilakukan sebagai upaya untuk memaksa pihak dimaksud agar melakukan atau tidak melakukan tindakan apa pun atau; kejahatan dilakukan oleh seseorang yang tidak memiliki kewarganegaraan yang berdomisili tetap di wilayah pihak dimaksud (Pasal 7 ayat (2) ASEAN Convention on Counter Terrorism).

9. Suatu negara pihak juga wajib menetapkan yurisdiksinya atas kejahatankejahatan yang tercakupi dalam Pasal 2 konvensi ini dalam hal tersangka pelaku kejahatan berada di dalam wilayah pihak dimaksud dan pihak tersebut tidak mengekstradisi tersangka dimaksud ke pihak-pihak mana pun yang telah menetapkan yurisdiksinya sesuai dengan ayat 1 atau 2 (Pasal 7 ayat (3) ASEAN Convention on Counter Terrorism).

10. Pasal 11 dalam ASEAN Convention on Counter Terrorism juga memuat sebuah program rehabilitasi ataupun deradikalisasi dengan tujuan mencegah terjadinya tindakan kejahatan terorisme. Adapun program rehabilitasi ini adalah dengan membina kembali para teroris yang telah ditangkap dan diadili untuk kembali ke masyarakat. Upaya dalam menangkal terorisme membutuhkan peranan tokoh agama, karena para tokoh agama dapat memberikan pencerahan pemikiran dan pengubahan 
pola pikir keagamaan umat yang radikal yang telah melakukan berbagai aksi terorisme sehingga kembali menjadi umat yang toleran.

11. Konvensi ini mengatur juga mengenai ekstadisi, bahwa pihak yang di wilayahnya tersangka pelaku kejahatan berada apabila tidak mengekstradisi orang tersebut, diwajibkan, tanpa pengecualian apa pun dan apakah kejahatan itu dilakukan atau tidak dilakukan di wilayahnya, menyerahkan kasus tersebut tanpa penundaan kepada otoritas berwenang untuk tujuan penuntutan, melalui proses hukum sesuai dengan peraturan perundang-undangan nasionalpihak tersebut (Pasal 13 ayat (1) ASEAN Convention on Counter Terrorism). Konvensi ini juga mewajibkan bagi negara pihak untuk memasukan jenis kejahatan sebagaimana telah disebutkan di dalam pasal 2 konvensi sebagai kejahatan yang dapat diestradisi dalam setiap perjanjian ekstradisi (Pasal 13 ayat (2) ASEAN Convention on Counter Terrorism). Adapun konvensi ini dapat dijadikan dasar hukum bagi pihak-pihak yang akan melakukan ekstradisi namun belum memiliki perjanjian sebelumnya, kemungkinan tersebut terdapat di dalam pasal 13 ayat (3) ASEAN Convention on Counter Terrorism.

12. Selain itu, konvensi ini mengatur tentang keterkaitan konvensi ini dengan instrumen internasional yang lain, hal tersebut diatur dalam pasal 18, yaitu:

This convention shall not derogate from obligations subsisting between the parties pursuant to other international agreements nor, where the parties agree, shall it prevent the parties from providing assistance to each other pursuant to other international agreements or the provisions of their respective domestic laws.

Pasal tersebut menjelaskan bahwa konvensi ini tidak membatasi atau menghilangkan hak-hak dan kewajiban antara negara-negara pihaknya terhadap dan sesuai dengan perjanjian-perjanjian yang telah disepakati maupun diratifikasi oleh negara-negara pihak tersebut.

13. ASEAN Convention on Counter Terrorismjuga memberikan ruang kepada negara-negara pihak untuk membentuk saluran-saluran komunikasi antar instansi yang berwenang untuk memfasilitasi pertukaran informasi guna mencegah terjadinya kejahatan-kejahatan yang tercakupi dalam pasal 2konvensi ini. Jika di kemudian hari terjadi sengketa karena perbedaan penafsiran setiap pasal konvensi ini, para pihak diwajibkan untuk menyelesaikannya secara damai melalui cara diplomatik atau cara damai lainnya (pasal 29).

Pada pemaparan bagian dari ASEAN Convention on Counter Terrorism terdapat beberapa poin utama yang bisa kita temukan. ASEAN sangat mengedepankan kerjasama berbasis diplomasi dan negosiasi antar anggota dalam menangani masalah terorisme, khususnya pembajakan di laut. ASEAN Convention 
on Counter Terrorism juga mengatur beberapa penjelasan mengenai ruang lingkup kerjasama yang mungkin dilakukan para anggota ASEAN, seperti pertukaran informasi/intelejen bersama, pengawasan perbatasan, pembekuan aset teroris, perjanjian ekstradisi, dan program rehabilitasi.

Namun, perlu digarisbawahi bahwa mekanisme kerjasama yang dilakukan bersifat koordinatif dan mengutamakan aspek yurisdiksi masing-masing negara. Sehingga jika mengacu pada konsep kerjasama internasional yang disinggung sebelumnya, hal ini merupakan suatu penyesuaian sikap atas kepentingan bersama. Penyesuaian sikap ini tidak menghilangkan sifat naluriah negara yang berdaulat atas yurisdiksinya masing-masing. Meskipun dalam kerjasama yang lain, sedikit atau sebagian kedaulatan negara bisa berkurang akibat adanya pengalihan kekuasaan kepada pihak yang lain atau terhadap badan supranasional, tetapi dalam organisasi ASEAN hal itu telah diatur dengan menetapkan prinsip nonintervensi. Prinsip non-intervensi di ASEAN memberikan hak kepada masingmasing negara anggota untuk mengurusi masalah nasionalnya masing-masing, sekalipun mereka telah dinyatakan resmi sebagai anggota organisasi.

Melalui konvensi ini kita juga dapat melihat komitmen yang sangat tinggi dari negara anggota ASEAN dalam melakukan kerjasama menangani masalah terorisme. Konvensi ini bukanlah pengaturan bersama pertama kali mengenai terorisme di kawasan Asia Tenggara. Menurut penulis dengan munculnya konvensi ini yang diawali dengan beberapa upaya-upaya bersama lainnya menunjukkan bahwa ada keseriusan dari para anggota ASEAN. Hal ini menjadi wajar jika kita melihat potensi kawasan Asia Tenggara yang sangat tinggi dan juga kerawanan yang juga cukup tinggi melihat aspek georgrafis dan juga potensi tersebut.

Meskipun masalah terorisme atau pembajakan di laut tidak berdampak ke seluruh negara ASEAN, tetapi isu ini menjadi hirauan dalam beberapa pertemuan ASEAN. Terdapat setidaknya tiga forum yang membahas mengenai keamanan maritim, yaitu ASEAN Maritime Forum (AMF), ASEAN Regional Forum InterSessional Meeting (ARF-ISM) on Maritime Security, dan Maritime Security Expert Working Group (MSEWG) (Amri, 2013: 12-13).Beberapa pertemuan tersebut juga menunjukkan kepada kita bahwa negara anggota ASEAN memiliki komitmen yang tinggi terhadap masalah terorisme laut. Pada bagian selanjutnya, penulis lebih spesifik menjelaskan mengenai penanganan terorisme yang terjadi di tahun 2016 pada laut perbatasan Indonesia, Malaysia, dan Filipina.

\section{e. Respon Indonesia, Malaysia, dan Filipina dalam Menyikapi Pembajakan Laut Tahun 2016}

Dikarenakan semua negara di ASEAN telah meratifikasi ASEAN Convention on Counter Terrorism, maka penulis berpendapat bahwa aturan yang tercantum di dalamnya dapat menjadi bahan acuan negara anggota dalam mengatasi masalah 
terorisme. Pada kasus yang sangat menarik di tahun 2016 adalah pembajakan kapal laut di perairan Sulu, Filipina oleh kelompok teroris Abu Sayyaf terhadap tiga buah kapal dalam kurun waktu satu bulan. Dua buah kapal asal Indonesia dan satu kapal asal Malaysia, serta para sandera dibawa ke daerah yurisdiksi Filipina. Permasalahan ini menyita perhatian pemimpin-pemimpin di tiga negara. Masalah yang melintasi batas negara ini, meliputi kewarganegaraan para sandera, kapal, lokasi pembajakan, penyanderaan, dan aktor pembajakannya, menuntut penyelesaian masalah yang bersifat lintas batas pula.

Ketiga negara merespon kejadian tersebut dengan beberapa upaya, yaitu meningkatkan kerjasama melalui beberapa perundingan dan kegiatan bersama ketiga negara. Pada Mei 2016, ketiga negara mengadakan pertemuan trilateral "2+2" antara menteri luar negeri dan Panglima Angkatan Bersenjata masingmasing atas inisiasi Indonesia di Yogyakarta. Menurut Menteri Luar Negeri Indonesia, Retno Marsudi, pertemuan tersebut juga menyiratkan pesan utama komitmen tinggi Indonesia, Malaysia, dan Filipina untuk memastikan perdamaian,stabilitas, dan keamanan di kawasan yang tidak saja berkontribusi pada kesejahteraan ekonomi ketiga negara, namun juga bagi ASEAN (Sindonews.com, http://international.sindonews.com /read/1106383/40/rifilipina-dan-malaysia-sepakat-kerjasama-intelijen-cegah-aksi-terorisme1462434445, akses 28 April 2019.)

Pertemuan ini menurut penulis merupakan salah satu bentuk pelaksanaan poin ACCT. Pada pertemuan tersebut disepakati beberapa hal, seperti akan ditingkatkan kerjasama antara pasukan tentara tiga negara di daerah perbatasan melalui patroli bersama, membuat pusat krisis di masing-masing negara dan sarana komunikasi darurat antar ketiga negara, akan diadakannya pertemuan lanjutan tingkat menteri pertahanan, dan akan diatur tata cara penyelesaian masalah pembajakan laut yang bersifat internasional di antara ketiga negara. Pertemuan ini juga mengawali pertemuan lainnya di tingkat regional dan global dalam mengatasi masalah terorisme.

Permasalahan laut perbatasan tiga negara lebih banyak diatasi secara nasional, akan tetapi melalui momentum pembajakan oleh Abu Sayyaf membuat ketiga negara merasa perlu meningkatkan perundingan trilateral bahkan dalam lingkup ASEAN atau global. Peningkatan kerjasama sesuai dengan poin konvensi yang diratifikasi tahun 2013 tersebut. Beberapa pertemuan lain yang menandai keseriusan ketiga negara maupun negara ASEAN menangani masalah terorisme di wilayah laut di antaranya adalah pertemuan menteri pertahanan Indonesia, Malaysia, dan Filipina dan Counter-Terrorism Summit 2016.

Pada tanggal 2 Agustus 2016, menteri pertahanan ketiga negara melakukan pembahasan keamanan di wilayah maritim Laut Sulu. Pertemuan melanjutkan pembahasan kerjasama ketiga negara mengenai keamanan laut yang sudah disepakati sebagai respon dari penculikan awak kapal yang terjadi di tahun 2016. 
Ketiga negara juga menyepakati patroli keamanan maritim yang telah ditandangani dalam dokumen "Framework of Arrangement" yang dibahas pada 14 Juli 2016 di Jakarta (Muhajir, http://www.benarnews.org/ indonesian/berita/pertemuan-menhan-trilateral-08022016140925.html,akses 28 April 2019).Menurut Emil Radiansyah, seorang pengamat hubungan internasional, konsep keamanan di perairan Indonesia, Malaysia, dan Filipina akan sama dengan kerja sama mengamankan Selat Malaka. Keduanya menganut prinsip "patroli terkoordinasi", dan bukan "patroli bersama". Perbedaaan keduanya pada ancaman keamanannya, di mana Selat Malaka lebih pada pengadangan perompak sementara di laut perbatasan tiga negara lebih ke peningkatan pengamanan dari penculikan dan penyanderaan kelompok $\mathrm{Abu}$ Sayyaf (Asia, https://www.jurnalasia. com/nasional/mencari-solusi-berantas-terorisme-di-perbatasan/ akses 28 April 2019).

Hal lain yang juga dibahas dalam pertemuan tersebut adalah usulan pembentukan posko militer bersama. Posko militer bersama ditujukan untuk mempermudah mekanisme kordinasi, serta distribusi informasi dan intelijen. Pertemuan menteri pertahanan tiga negara merupakan pertemuan ketiga yang membahas langkah lanjutan dua pertemuan sebelumnya di Laos di sela-sela ASEAN Defence Minister Meeting pada Mei 2016 dan di Filipina pada Juni 2016 (Muhajir, http://www.benarnews.org/indonesian/berita/pertemuan-menhantrilateral-08022016140925.html,akses 28 April 2019).Kerjasama regional sekaligus global yang juga menjadi respon dari permasalahan pembajakan di tahun 2016 adalah diadakannya CTF Summit 2016. Pertemuan diselenggarakan lembaha intelijen keuangan Indonesia dan Australia. Tujuan pertemuan ini adalah untuk menambah pengalaman dan pengetahuan bersama negara peserta pertemuan dalam mencegah, menanggulangi dan memerangi kegiataan pendanaan terorisme (Liputan6.com, http://global.liputan6.com/read/2569380/bali-jadi-tuan-rumahpertemuan-global-anti-terorisme, akses 28 Agustus 2019).

Perundingan-perundingan tersebut menghasilkan beberapa bentuk kerjasama antara ketiga negara. Pertama, disepakati diadakannya patroli bersama antara ketiga negara. Pertemuan antara Menteri Luar Negeri dan Panglima TNI tiga negara tersebut sepakat melakukan patroli terkordinasi di perairan yang menjadi kepentingan bersama (Sindonews.com, http://international.sindonews.com/ read/1106383/40/ri-filipina-dan-malaysia-sepakat-kerjasama-intelijen-cegah-

aksi-terorisme-1462434445, akses 28 April 2019).Kegiatan patroli bersama yang disepakati bertujuan untuk menghindari dan mengatasi peningkatan masalah keamanan di laut perbatasan mereka (Parameswaran, http://thediplomat. com/2016/05/indonesia-philippines-malaysia-agree-on-new-joint-patrols-amidkidnappings/ akses 25 April 2019). Perlu digarisbawahi bahwa patroli tetap mengacu pada prinsip yurisdiksi masing-masing.Ketiga negara juga sepakat akan meningkatkan koordinasi pemberian bantuan cepat bagi warga dan kapal dalam 
keadaan bahaya (Sindonews.com, http://international.sindonews.com /read/1106383/ 40/ri-filipina-dan-malaysia-sepakat-kerjasama-intelijen-cegahaksi-terorisme-146243 4445, akses 28 April 2019).Kedua, disepakati pembagian informasi intelejen mengenai teroris maupun aktifitas mereka di negara masingmasing. Ketiga, kesepakatan pendirian posko bersama tanggap darurat masalah pembajakan.

Keempat, membuat kesepakatan rute aman pelayaran. Pembahasan rute pelayaran juga menjadi isu yang sangat penting dalam perundingan ketiga negara. Patroli bilateral antara Indonesia dan Filipina sudah pernah dilakukan terhadap rute pelayaran tersebut berdasarkan kesepakatan sebelumnya. Di samping itu juga ketiga negara sepakat mengamankan jalur pelayaran dengan menyertakan tentara di kapal-kapal komersial untuk melakukan pengawalan (Muhajir, http://www. benarnews.org/indonesian/berita/pertemuan-menhan-trilateral08022016140925. html, akses 28 April 2019).

Kelima, kesepakatan latihan militer bersama. Berdasarkan pengalaman kerjasama Malaysia dan Filipina, kedua negara telah melakukan pelatihan laut bersama di bulan Agustus. Pada prinsipnya ketiga negara memiliki kesepakatan bersama mengenai pengamanan wilayah perbatasan. Seperti antara Malaysia dan Filipina telah memiliki memorandum of understanding on defense cooperation yang disepakati tahun 1994 (Diplomat, http://thediplomat.com/2015/08/philippinesmalaysia-hold-joint-naval-exercises-amid-security-concerns/2/, akses 28 April 2019.)

Pada bagian selanjutnya penulis menyampaikan analisis mengenai kendala penyelesaian masalah terorisme laut di wilayah perbatasan Indonesia, Malaysia, dan Filipina. Beberapa argumen yang penulis sampaikan meliputi sifat respon atas terorisme yang temporer, hubungan antara kerjasama dan kedaulatan, perbedaan kesadaran wilayah laut, perbedaan sikap atas rezim Regional Cooperation Agreement on Combating Piracy and Armed Robbery Against Ships in Asia (ReCAAP).

Pertama, respon atas masalah terorisme bersifat situasional. Komitmen anti terorisme memang dipertegas dalam perundingan-perundingan, tapi ketika ditataran teknis terdapat ketidakmaksimalan penerapan. Hal ini terbukti dengan telah disepakatinya ASEAN Convention on Counter Terrorism di tahun 2007 dan diratifikasi oleh semua negara anggota tahun 2013, namun di tahun 2016 kasus pembajakan terjadi oleh aktor yang sama di wilayah laut yang hampir sama terhadap tiga kapal dalam kurun waktu satu bulan. Ketiga negara merevisi kembali persetujuan dan pengaturan masing-masing mengenai masalah wilayah laut. Meskipun perlu diakui respon ketiga negara begitu cepat dengan melakukan pertemuan-pertemuan trilateral. Tetapi, pada aspek pencegahan perlu menjadi perhatian bahwa ada ketidaksiapan negara-negara dalam menyikapi fenomena pembajakan laut di sekitar laut perbatasan perairan Sulu. 
Salah satu alasan yang menurut penulis dapat diterima adalah perhatian ketiga negara selama ini bukan di wilayah laut Sulu.

Karena Abu Sayyaf selama ini banyak beroperasi di daratan wilayah Filipina. Kalau pun ada pembajakan laut selama ini banyak terjadi di Selat Malaka atau Laut Tiongkok Selatan yang memiliki intensitas perdagangan lebih tinggi. Sehingga wilayah utara Kalimantan tidak terlalu menjadi perhatian. Di samping itu, modus pembajakan yang berubah juga menjadi hal yang baru bagi ketiga negara. Penulis sudah pernah menyinggung poin ini sebelumnya bahwa di tahun 2016 pola pembajakan adalah dengan menahan sandra dan meminta tebusan. Sementara sebelumnya para awak kapal cenderung dibebaskan dan para pembajak/teroris hanya tertarik pada kapal dan isinya saja. Pergesaran objek keamanan dari kapal ke manusia ini memerlukan penanganan yang berbeda, baik dalam menyelesaikan masalah penyanderaan maupun pencegahan supaya terorisme di wilayah laut tidak terjadi lagi.

Kedua, kendala menghubungkan antara kerjasama dan kedaulatan negara. Beberapa ahli berpendapat bahwa upaya yang dilakukan oleh negara-negara ASEAN secara kolektif selama ini sering terbentur masalah kordinasi dan prinsip non-intervensi. Prinsip non-intervensi ini diatur dalam Treaty of Amity and Cooperation in Southeast Asia, khususnya pada pasal 2. Menurut Espenilla, kerjasama Indonesia, Malaysia, dan Filipina harus memiliki kejelasan dalam batas dari patroli laut yang akan dilakukan bersama (Espenilla, http://thediplomat.com/2016/05/abductions-at-sea-a-3-way-security-challengefor-indonesia-malaysia-and-the-philippines/, akses 25 April 2019).

Berdasarkan data yang beliau temukan, pemerintah Filipina menekankan pada patroli secara terpisah di masing-masing yurisdiksi nasional tetapi bersifat koordinatif dengan negara tetangga. Sementara Indonesia mengusulkan patroli bersama ketiga tentara negara di wilayah mereka bersama, sehingga memungkinkan tentara negara tetangga masuk ke wilayah yurisdiksi negara lainnya. Penulis berpendapat bahwa kedua opsi ini sangat mungkin terjadi karena pertama Filipina mengedepankan prinsip kedaulatan wilayah negara, sementara Indonesia mengedepankan pada pentingnya masalah sehingga perlu ada penyesuaian terhadap posisi kedaulatan.

Menteri Koordinator Bidang Politik, Hukum, dan Keamanan Indonesia mengakui kerja sama pengamanan kawasan perairan antara Indonesia, Filipina, dan Malaysia hingga saat ini belum berjalan. Hal ini disebabkan pada perbedaan sudut pandang antar ketiga Negara (Kompas.com, http://nasional. kompas.com/read/2016/06/24/15073791/wni.disandera.lagi.di.perairan.sulu.lu hut.akui.kerja.sama.kawasan.belum.berjalan pada 28 April 2019). Menyikapi kerjasama yang belum berjalan, beliau juga berharap pemerintah Filipina yang baru memiliki komitmen yang tinggi dalam menyelesaikan masalah bersama ini. 
Perbedaan sikap ini merupakan suatu hal yang lumrah dalam pembahasan antar negara. Bahkan sering kita menemukan perbedaan pendapat antar individu. Apalagi negara memiliki atribut kepentingan nasional yang merupakan tujuan utama yang harus dicapai sekaligus dijaga.

Sehingga wajar saja jika masing-masing bersikap menyesuaikan dengan kepentingan masing-masing. Namun, tetap harus diperhatikan sesuai dengan amanat dari konvensi bahwa masing-masing negara anggota mengedepankan prinsip kerjasama dengan perundingan yang damai.

Masalah lain yang dihadapi oleh ketiga negara adalah perbedaan kesadaran atas wilayah laut dan kemampuan pengawasan serta penegakan hukum yang berbeda di masing-masing Negara (Espenilla, http://thediplomat.com /2016/05/abductions-at-sea-a-3-way-security-challenge-for-indonesia-malaysiaand-the-philippines/, akses 25 April 2019). Espenilla menyebutkan masalah ini juga menjadi salah satu sebab perbedaan cara pandang negara-negara dalam menjabarkan bentuk kerjasama yang akan mereka lakukan. Hal ini juga tidak bisa dipungkiri mengingat bahwa kemampuan patroli dan penegakan hukum adalah wewenang pemerintah negara masing-masing.

Pendapat mengenai kerjasama di ASEAN dalam mengatasi masalah terorisme laut disampaikan oleh Peter Chalk. Menurut Chalk, perbedaan kapasitas antara tentara dan alutsista Indonesia, Malaysia, dan Filipina menjadi salah satu penyebab kerawanan yang terjadi di perairan ketiga Negara (Sim, http://www.straitstimes.com/asia/se-asia/cooperation-is-key-for-asean-to-fightterror-say-experts, akses 28 April 2019). Malaysia sebagai negara yang paling baik perlengkapan dan persenjataannya dibandingkan kedua negara lainnya. Chalk juga menambahkan bahwa dalam kerangka pilar Politik dan Keamanan ASEAN, kerjasama menjadi resep utama dalam penanggulangan masalah terorisme di kawasan Asia Tenggara. Pendapat tersebut mendukung data bahwa terdapat perbedaan kesadaran maritim di antara ketiga negara.

Alasan di atas juga ditentukan oleh faktor politik dalam negeri. Meskipun selama ini telah terdapat upaya secara nasional dari masing-masing negara ASEAN, Rohan Gunaratna, Kepala International Centre for Political Violence and Terrorism Research Singapura masih menilai bahwa kerjasama merupakan keharusan. Beliau menyarankan adanya pusat data bersama, pertukaran personil dan operasi maupun latihan bersama untuk mengatasi teroris (Sim, http://www. straitstimes.com/asia/se-asia/cooperation-is-key-for-asean-to-fight-terror-sayexperts, akses 28 April 2019).

Menyikapi kedua tantangan tersebut, Espenilla menyarankan perlunya ketiga negara atau negara-negara ASEAN meniru penjabaran konsep kordinasi yang diterapkan pada the Code of Conduct Concerning the Repression of Piracy, Armed Robbery Against Ships, and Illicit Maritime Activity in West and Central Africa (Yaoundé Code of Conduct) dan the Code of Conduct Concerning the Repression of 
Piracy and Armed Robbery Against Ships in the Western Indian Ocean and the Gulf of Aden (Djibouti Code of Conduct)(Sim, http://www.straitstimes.com/asia/seasia/cooperation-is-key-for-asean-to-fight-terror-say-experts, akses 28 April 2019). Kedua aturan tidak mengikat tersebut terbukti telah efektif menekan angka pembajakan di teluk Guinea dan pantai Somalia dengan tetap mengedepankan pada prinsip kedaulatan dan non-interfensi antar negara. Negara-negara di ASEAN, khususnya Indonesia, Malaysia, dan Filipina dapat melakukan pertukaran informasi dengan negara-negara di sekitar Guinea dan Somalia mengenai aturan tersebut. Belajar dari kawasan lain juga bisa menjadi salah satu opsi yang menarik, mengingat permasalahan pembajakan di wilayah Guinea dan Somalia juga termasuk kasus-kasus yang besar dan sering menarik perhatian dunia internasional.

Kendala standar kesadaran wilayah laut yang harus ditingkatkan. Seperti yang telah dibahas sebelumnya bahwa terdapat perbedaan pada kesadaran wilayah laut dan kemampuan pengamanan wilayah laut. Pendapat Espenilla hal ini sangat menentukan bagaimana negara-negara di wilayah konflik menyikapi masalah atau bahkan dalam upaya mencegah munculnya konflik-konflik baru (Sim, http://www.straitstimes.com /asia/se-asia/cooperation-is-key-for-asean-to-fightterror-say-experts, akses 28 April 2019). Ketidaksiapan salah satu negara dapat berpengaruh pada keamanan bersama di wilayah laut bersama. Para pembajak akan lebih memilih beroperasi di wilayah laut yang tingkat pengamanannya lebih rendah. Perlu juga kita ingat bahwa selama ini masing-masing negara menjaga wilayah lautnya masing-masing. Hal ini yang coba didobrak oleh pemerintah Indonesia melalui usulan bebas akses di wilayah laut perbatasan sebagai alternatif menjembatani kesenjangan kesadaran maritim tersebut.

Ketiga, terdapat perbedaan sikap dalam menyikapi Regional Cooperation Agreement on Combating Piracy and Armed Robbery Against Ships in Asia (ReCAAP). Rezim ini ditandatangani oleh 20 negara yang salah satunya adalah Filipina. Namun, yang menjadi menarik adalah tidak ada nama Indonesia dan Malaysia dalam daftar nama anggota. Indonesia beralasan dengan ikut dalam pengaturan skala besar yang terdiri dari 20 anggota akanmembahayakan kedaulatan mereka. Perlu diketahui bahwa di dalam keanggotaan tersebut terdapat beberapa negara superpower seperti Amerika Serikat, Tiongkok, Jepang, Inggris, serta tetangga dekat Indonesia yang sering berseteru, yaitu Australia. Karena kepentingan yang berbeda-beda dari masing-masing kekuatan negaranegara di dunia sehingga menurut penulis Indonesia lebih berhati-hati dalam membahas isu yang memungkinkan kedaulatan mereka berkurang.

Sekilas dapat kita katakan Indonesia bermain di dua kaki, di satu sisi ketika berunding dengan Filipina dan Malaysia ingin adanya kedaulatan yang dibagi bersama melalui akses bebas patroli. Tetapi, di sisi lain saat berunding dengan negara-negara di luar ketiga negara tersebut Indonesia sangat menjaga 
prinsip kedaulatannya. Hal ini menurut penulis disebabkan oleh kepentingan dan daya tawar yang dimiliki oleh Indonesia.

Pada skala regional, Indonesia masih memiliki nilai tawar yang baik antar kedua negara tetangga. Ketimbang Indonesia masuk ke pengaturan yang melibatkan negara-negara adikuasa tersebut. Posisi tawar Indonesia yang lebih tinggi dari Filipina juga digunakan Indonesia untuk menekan pemerintah Filipina agar serius menyikapi ancaman teror Abu Sayyaf. Indonesia menerapkan moratorium ekspor batubara ke Filipina karena menilai Filipina lalai dalam mengamankan wilayah lautnya. Filipina sangat bergantung pada ekspor batubara dari Indonesia dan moratorium baru dicabut setelah Filipina benar-benar menjamin keselamatan WNI yang masuk ke wilayahnya (Kompas.com,http://nasional.kompas.com/read/2016/06/24/15073791/wni.dis andera.lagi.di.perairan.sulu.luhut.akui.kerja.sama.kawasan.belum.berjalan, akses 28 April 2019).

Malaysia juga memiliki kepentingannya atas ketidakikutsertaannya di rezim tersebut. Menurut temuan penulis, hal ini karena markas dari ReCAAP akan berada di Singapura (Espenilla, http://thediplomat.com/2016/05/abductions-atsea-a-3-way-security-challenge-for-indonesia-malaysia-and-the-philippines/,

akses 25 April 2019). Sementara Malaysia sendiri memiliki lembaga pelaporan pembajakan di Kuala Lumpur. Keberadaan dua pusat pelaporan pembajakan dapat menjadi pemicu kesimpangsiuran informasi serta konflik antara dua negara bertetangga. Malaysia menurut penulis merasa wewenangnya tersaingi dalam mengurusi permasalahan pembajakan melalui lembaganya. Selama ini Malaysia menjadi rujukan informasi mengenai pembajakan di kawasan. Posisi tawar yang meningkatkan posisi Malaysia ini menurut penulis coba dipertahankan dengan tidak mengikuti kesepakatan tersebut. Mungkin saja atas inisiatif forum, posisi lembaga Malaysia harus tunduk ke pusat informasi di Singapura. Menyikapi hal tersebut, perlu diperhatikan fokus penyelesaian masalah dilakukan oleh ketiga negara saja tanpa memasukkan unsur luar kawasan ke dalam penyelesaian masalah. Semakin sedikit aktor yang berkordinasi akan lebih baik.

\section{PENUTUP}

Permasalahan terorisme di Asia Tenggara, khususnya di zona maritim merupakan isu bersama yang menjadi hirauan seluruh negara anggota ASEAN. Beberapa perundingan dan kesepakatan telah dilaksanakan oleh negara-negara ASEAN, yang salah satunya adalah Konvensi ASEAN Melawan Terorisme. Pada konvensi tersebut diberikan acuan penanganan bersama masalah terorisme di kawasan Asia Tenggara. Implementasi konvensi dalam kasus pembajakan di laut perbatasan Indonesia, Malaysia, dan Filipina dilakukan melalui prinsip kerjasama. Kerjasama di tahun 2016 dilakukan dengan melaksanakan beberapa perundingan, seperti pertemuan trilateral menteri luar negeri dan panglima bersenjata ketiga 
negara, pertemuan menteri pertahanan ketiga negara, dan CTF Summit. Pada beberapa perundingan disepakati bahwa ketiga negara akan melakukan patroli terkordinasi, pembangunan posko bersama, pembagian informasi intelijen mengenai aksi atau pelaku terorisme, membuat kesepakatan rute pelayaran, dan latihan militer bersama. Namun, implementasi konvensi belum efektif karena masih menghadapi beberapa kendala seperti sifat tanggapan atas terorisme yang situasional, kendala di kedaulatan negara dan prinsip non-interfensi antar anggota, perbedaan dalam kesadaran wilayah laut, dan perbedaan sikap atas rezim ReCAAP.

Adapun yang dapat dilakukan bagi pembuat kebijakan di Indonesia, Malaysia, dan Filipina adalah perlu diambil tindakan pengamanan esktra terhadap masalah terorisme di laut perbatasan. Ketiga negara juga dapat melakukan proses sekuritisasi terhadap masalah keamanan tersebut. Hal ini perlu dilakukan secara cepat karena kasus yang terjadi dalam sebulan terdapat tiga kali insiden penyanderaan kapal. Upaya perundingan-perundingan harus lebih bisa diterjemahkan ke dalam aksi yang nyata. Kesadaran ini dapat diterjemahkan pada upaya pengamanan yang lebih baik terhadap yurisdiksi lautnya masing-masing. Sehingga dapat mengurangi potensi munculnya insiden-insiden pembajakan lainnya.

\section{DAFTAR PUSTAKA}

\section{A. Buku}

ASEAN. 2009. ASEAN Political and Security Blueprint. Jakarta: ASEAN Secretariat.

Cryer, Robert, et. Al. 2010. An Introduction to International Criminal Law and Procedure. Cambridge: Cambridge University Press.

Kraska, James. 2011. Contemporary Maritime Piracy International Law, Strategy, and Diplomacy at Sea. California: Praeger.

Oppenheim. 1955. International Law A Treatise Vol. I-Peace. London: Longmas.

Santoso, Imam. 2014. Hukum Pidana Internasional. Bandung: Pustaka Reka Cipta.

Shaw, Malcom N. 2003. International Law Fifth Edition. Cambridge: Cambridge University Press.

Soekanto, Soerjono dan Sri Mamuji. 2006. Penelitian Hukum Normatif Suatu Tinjauan Singkat. Jakarta: Raja Grafindo Pustaka.

Thontowi, Jawahir. 2016. Hukum dan Hubungan Internasional. Yogyakarta: UII Press.

Ummar, M. Husseyn. 2001. Hukum martim dan Masalah-masalah Pelayaran Di Indonesia. Jakarta: Sinar Harapan. 


\section{B. Peraturan Internasional}

United Nations Convention on the Law of the Sea 1982

The Arab Convention For The Suppression Of Terrorism 1998

ASEAN Convention on Counter Terrorism 2007

\section{Sumber lainnya}

Amri, Ahmad. 2013. "Combating maritime piracy in Southeast Asia frominternational and regional legal perspectives: challenges and prospects". Dipresentasikan pada the Southeast Asia Rising! Proceedings of the 5th International Conference on Southeast Asia, Kuala Lumpur, Indonesia, 11-13 Desember 2013.

Azis, Abdul. 2016. "Panglima TNI Ungkap Motif Pembajakan Kapal oleh Abu Sayyaf". Dikutip dari https://m.tempo.co/read/news/2016/03/30/078758151/panglima-tniungkap-motif-pembajakan-kapal-oleh-abu-sayyafpada tanggal 18 April 2019.

Espenella, Jacqueline. 2016. "Abductions at Sea: A 3-Way Security Challenge for Indonesia, Malaysia, and the Philippines". The diplomat. Dikutip dari http://thediplomat.com/2016/05/abductions-at-sea-a-3-way-securitychallenge-for-indonesia-malaysia-and-the-philippines/ pada tanggal 25 April 2019.

Harian Jurnal Asia. 2016. "Mencari Solusi Berantas Terorisme di Perbatasan". Dikutip dari https://www.jurnalasia.com/nasional/mencari-solusiberantas-terorisme-di-perbatasan/ pada tanggal 28 April 2019.

Kuhnert, Lara E. 2006. "Maritime Terrorism in Southeast Asia". University of Tennessee Honors Thesis Projects. Dikutip dari http://trace. tennessee.edu/utk_chanhonoproj/983 pada 23 April 2019.

Kompas.com. 2016. "Ini Kronologi Penyanderaan 10 ABK oleh Kelompok Abu Sayyaf". Dikutip dari http://nasional.kompas.com/read/2016/05 /02/16455111/Ini.Kronologi.Penyanderaan.10.ABK.oleh.Kelompok.Abu.Sayyafp ada tanggal 18 April 2019.

Kompas.com. 2016. "WNI Disandera Lagi di Perairan Sulu, Luhut Akui Kerja Sama Kawasan Belum Berjalan". Dikutip dari http://nasional. kompas.com/read/2016/06/24/15073791/wni.disandera.lagi.di.perairan .sulu.luhut.akui.kerja.sama.kawasan.belum.berjalan pada 28 April 2019.

Liputan6.com. 2016. "Bali Jadi Tuan Rumah Pertemuan Global Anti Terorisme". Dikutip dari http://global.liputan6.com/read/2569380/bali-jadi-tuanrumah-pertemuan-global-anti-terorisme pada tanggal 28 April 2019. 
Mccauley, Adam. 2014. “The Most Dangerous Waters In The World”. Dikutip dari http://time.com/piracy-southeast-asia-malacca-strait/pada tanggal 29 April 2019.

Muhajir, Anton. 2016. "Menhan Tiga Negara Bahas Keamanan Maritim di Bali". Dikutip dari http://www.benarnews.org/indonesian/berita/pertemuanmenhan-trilateral-08022016140925.html pada tanggal 28 April 2019.

Mulyono, Hersapta. 2014. "Yo Ho Ho And A Bucket Of Cash The Need To Enhance Regional Effort To Combat Piracy And Armed Robbery Against Ships In Southeast Asia". Indonesian Journal of International Law, vol 12, no. 1: 6083

Parameswaran, Prashanth. 2016. "Indonesia, Philippines, Malaysia Agree on New Joint Patrols Amid Kidnappings“. The diplomat. Dikutip dari http://thediplomat.com/2016/05/indonesia-philippines-malaysia-agree-onnew-joint-patrols-amid-kidnappings/ pada tanggal 25 April 2019.

Pushpanathan, S. "ASEAN Efforts to Combat Terrorism". ASEAN. Dikutip dari http://asean.org/?static_post=asean-efforts-to-combat-terrorism-byspushpanathan pada tanggal 25 April 2019.

Sim, Melissa. 2015. "Cooperation is key for Asean to fight terror', say experts". Dikutip dari http://www.straitstimes.com/asia/se-asia/ cooperation-is-key-for-asean-to-fight-terror-say-experts pada tanggal 28 April 2019.

Sindonews.com. 2016. "RI, Filipina, dan Malaysia Sepakat Kerjasama IntelijenCegah Aksi Terorisme”. Dikutip dari http://international. sindonews.com/read/1106383/40/ri-filipina-dan-malaysia-sepakatkerjasama-intelijen-cegah-aksi-terorisme-1462434445 pada tanggal 28 April 2019.

The Diplomat. 2015. "Philippines, Malaysia Hold Joint Naval Exercises AmidSecurity Concerns". Dikutip dari http://thediplomat. com/2015/08/philippines-malaysia-hold-joint-naval-exercises-amidsecurity-concerns/ 2/ pada tanggal 28 Agustus 2016.

United Nations. 2016. "Chronological lists of ratifications of, accessions and successions to the Convention and the related Agreements". Dikutip dari http://www.un.org/depts/los/reference_files/chronological_lists_of_ratifications .htm pada tanggal 15 Agustus 2016.

Yani, Yanyan M. 2012. "Keharmonisan Kerjasama Kontra Terorisme NegaraNegara Anggota ASEAN dalam Kerangka ASEAN Security Community". Jurnal UNPAD, Volume 1 No. 2: hlm. 72-84. 


\section{PEDOMAN PENULISAN JURNAL PRANATA HUKUM}

1. Naskah bersifat orisinil, baik berupa hasil riset atau tinjauan atas suatu permasalahan hukum yang berkembang di masyarakat (artikel lepas), dimungkinkan juga tulisan lain yang dipandang memberikan kontribusi bagi pengembangan ilmu hukum.

2. Penulisan terdiri atas beberapa bab penulisan hasil penelitian terdiri dari 3BAB,yaitu ;

BAB I. PENDAHULUAN (Latar Belakang dan Rumusan Masalah) BAB II. PEMBAHASAN (Kerangka Teori dan Analisis), dan BAB III. PENUTUP (Kesimpulan dan Saran).

3. Tulisan menggunakan bahasa indonesia maupun bahasa inggris yang memenuhi kaidah bahasa yang baik dan benar,tulisan menggunakan bahasa indonesia disertai abstrak dalam bahasa inggris (200 kata) dan Kata kunci, ketentuan ini berlaku sebaliknya.

4. Setiap kutipan harus menyebutkan sumbernya, dan ditulis pada akhir kutipan dengan memberi tanda kurung (bodynote). Sumber kutipan harus memuat nama pengaran, tahun penerbitan dan halaman .Contoh : satu penulis (Bagir Manan, 1994: 20), Dua Penulis (Jimly Asshidiqqie dan M.Ali Syafa'at, 2005: 11), Tiga atau lebih penulis menggunakan ketentuan et.al (dkk). Untuk artikel dari internet dengan susunan: nama penulis, judul tulisan digaris bawah, alamat website, waktu download/unduh.

5. Naskah harus disertai dengan daftar pustaka atau referensi ,terutama yang digunakan sebagai bahan acuan langsung. Daftar pustaka dan referensi bersifat alfabetis dengan format; nama pengarang, judul buku, nama penerbit, kota terbit, dan tahun penerbitan. Contoh: Bagir Manan, Hubungan Antara Pemerintah Pusat dan Daerah Menurut UUD 1945, Pustaka Sinar Harapan, Jakarta, 1994.

6. Panjang tulisan antara 15-25 halaman, font times new roman dengan 1,15 spasi. Dalam hal hal tertentu berlaku pengecualian panjang tulisan.

7. Naskah disertai nama lengkap penulis, alamat e-mail dan lembaga tempat berafiliasi saat ini, dan hal lain yang dianggap penting. 


\section{Jurnal PRANATA HUKUM dimaksudkan sebagai}

media komunikasi, edukasi, dan informasi ilmiah bidang ilmu hukum khususnya, dan ilmu sosial pada umumnya. Sajian dan kemasan diupayakan komunikatif melalui bahasa ilmiah.

Redaksi mengundang semua elemen masyarakat baik civitas akademika, praktisi, lembaga masyarakat, maupun perorangan yang berminat terhadap bidang hukum untuk berpartisipasi mengembangkan gagasan, wawasan, dan pengetahuan melalui tulisan untuk dimuat dalam jurnal ini.

Melalui PRANATA HUKUM diharapkan terjadi proses pembangunan dan pengembangan bidang hukum sebagai bagian penting dari rangkaian panjang proses memajukan masyarakat bangsa.

Alamat Redaksi

PRANATA HUKUM

Kampus B Universitas Bandar Lampung Jl. ZA Pagar Alam No.89 Labuhan Ratu, Bandar

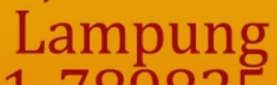

Telp: 0721-789825

Email: jurnal.mh@ubl.ac.id

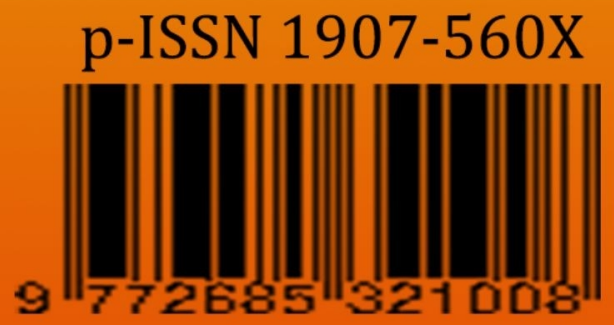

